\title{
Letter from China: covid-19 on the grapevine, on the internet, and in commerce
}

In medically murky times in China, people are turning to rumour, hope, and faith to protect themselves from the new coronavirus. In Beijing, Heather Mowbray is hearing all sorts of stories about how to stop the virus-but scientific evidence for the advice is woefully absent

\author{
Heather Mowbray
}

Beijing

Here's one example of the ideas floating around in China. Radio Free Asia reported that a Tibetan man named Tse was encouraging people to recite and forward a Buddhist prayer as a safeguard against the new coronavirus, covid-19. He was arrested for his efforts. Spreading rumours can land you in jail for seven years.

Community imposed social isolation means that everyone has plenty of time to read the latest news and advice online. Children have web based schooling, and adults do their searches from the kitchen table. The news aggregator Jinri Toutiao has leapt to the top of the app download list in the past month. Weibo, a blog platform somewhere between Twitter and Facebook, is ubiquitous.

Doctors, patients, and volunteer nurses make for the most captivating, if tragic, of the stories online. On the night that the whistleblower ophthalmologist Li Wenliang died, Katharina Qi, a policy adviser based in Beijing, read and shared people's stories online. Weibo users claimed to know Li's family and said that he was being rescued, hours after his heart had stopped. Some wrote that his family were also infected, including his pregnant wife in hospital. In reality, his parents had recovered, his wife was not infected, and the suppression of facts regarding his death left Qi and other internet users deeply disillusioned.

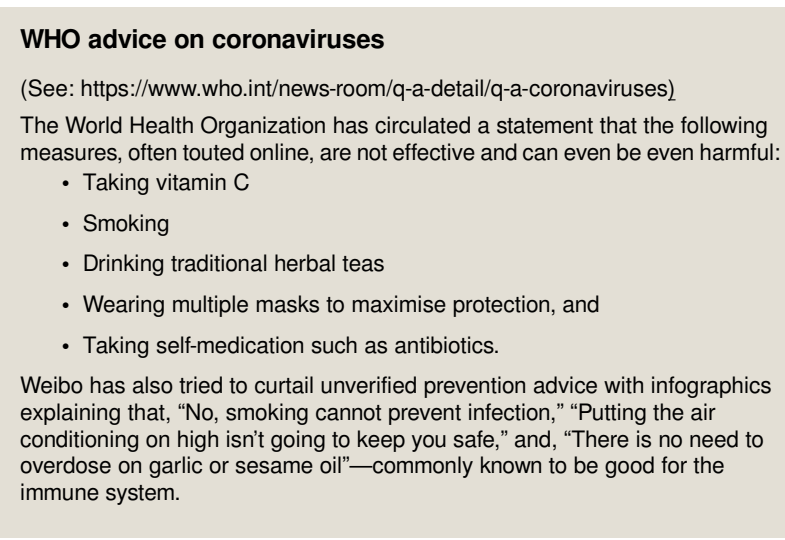

But it can be hard to know what to believe when you can't trust the official news. And, in Chinese medical advertising, anything goes. One herbal potion, Shuang-Huang-Lian, has sold out all over the country. Shelley Ochs, a traditional Chinese medicine educator raised in the US and trained in Beijing, told The BMJ that promoting Shuang-Huang-Lian did not ring true from a medical standpoint. In fact, the nature of the illness caused by covid-19 means that this remedy may be counterproductive. "Throwing cold and bitter herbs at the body could actually drive the 'external pathogens' deeper and make recovery both longer and more difficult," said Ochs.

It's harder still when the government supports the combined use of Chinese and Western medicine for prevention and cure. After the SARS epidemic 17 years ago, WHO sanctioned studies into herbal treatments for regaining bone density after excessive steroid use. Once covid-19 fades away, it may well be that one component in Shuang-Huang-Lian is found to inhibit the disease. However, says Ochs, "inhibition in a Petri dish is several important and arduous steps away from showing positive results for preventing the virus in humans." She emphasises that "the 
road from laboratory findings to animal testing to human clinical trials is a long one."

The device market is also heating up. Ian Lipkin, an epidemiologist advising the government on its response to covid-19, was alarmed by the number of diagnostic gizmos shown to him by salespeople on his latest visit in early February. This was something he had not seen in other outbreaks, he told Beijing based foreign correspondents in a call on 9 February, from self-quarantine in the US.

It's ironic that covid-19's crossover to humans in December is likely to have taken place at a market known for selling seafood and exotic animals used at the more mystical end of traditional Chinese health practices-virility, longevity, immunity. For now, the sale of exotic ingredients has been banned, and, as Lipkin remarked, this outbreak will probably be the "nail in the coffin for the sale of wild animals in China."

Meanwhile, people are waiting impatiently for evidence based responses from both traditional and Western medicine, which could take months or years.

Competing interests: I have read and understood BMJ policy on declaration of interests and have no relevant interests to declare.

Provenance and peer review: Commissioned; not externally peer reviewed.

Published by the BMJ Publishing Group Limited. For permission to use (where not already granted under a licence) please go to http://group.bmj.com/group/rights-licensing/ permissions 